\title{
SULFURATION TREATMENT OF ELECTROPLATING WASTEWATER FOR SELECTIVE RECOVERY OF COPPER, ZINC AND NICKEL RESOURCE
}

\author{
T. FUKUTA ${ }^{1, *}$ \\ H. MATSUDA ${ }^{1}$ \\ F. SETO ${ }^{2}$ \\ K. YAGISHITA ${ }^{2}$
}

Received: 30/5/2005

Accepted: $15 / 2 / 2006$
${ }^{1}$ Department of Energy Engineering and Science

Nagoya University, Furo-cho

Chikusa-ku, Nagoya 464-8603 Japan

${ }^{2}$ Sanshin MFG. CO., LTD. 1-2 Kifuneura

Haguro, Inuyama, Aichi, 484-0894 Japan

*to whom all correspondence should be addressed: e-mail: tfukuta@ybb.ne.jp

\begin{abstract}
In the electroplating process, various metal salts are used and the residues on the surface of electroplated materials are rinsed out as wastewater, followed by hydration in a wastewater disposal step. Although a variety of metals are concentrated in the sludge, the mixed heterogeneous state of these metals in sludge makes it difficult to recycle and reuse them. From the viewpoint of environmental protection as well as resource saving, effective methods for recycling and reuse of these mixed metal sludge are required to be developed urgently.

In the present work, selective recovery of the metals from mixed-metal wastewater by sulfuration treatment is proposed. Sulfuration treatment is characterized by low solubility of metal sulfides; metal sulfides are, in general, lower in solubility than that of metal hydroxides. For the experiments, three metals of copper, zinc and nickel which are commonly used in the electroplating process were chosen. Separation of these metals from the mixed solution in various $\mathrm{pH}$ ranges was conducted by employing three sulfurating agents: sodium sulfide $\left(\mathrm{Na}_{2} \mathrm{~S}\right)$, sodium disulfide $\left(\mathrm{Na}_{2} \mathrm{~S}_{2}\right)$ and sodium tetrasulfide $\left(\mathrm{Na}_{2} \mathrm{~S}_{4}\right)$. Aqueous solutions of $\mathrm{CuSO}_{4}, \mathrm{ZnSO}_{4}$ and $\mathrm{NiSO}_{4}$ and those of real plating wastewater, of which the initial concentrations were adjusted to $100-300 \mathrm{mg} \mathrm{dm}^{-3}$ were employed.

By sulfuration treatment of the simulated solution using each sulfurating agent without adjusting $\mathrm{pH}$, CuS was first precipitated, but ZnS and NiS were also precipitated at the same time. In addition, pH value increased with the amount of sulfurating agents in the solution. The results demonstrated that the formation behavior of metal precipitates depended on $\mathrm{pH}$ value of the solution. For the sulfuration with three kinds of sulfurating agents, copper was first separated from the solution as CuS in $\mathrm{pH}=1.4-1.5$, then $\mathrm{ZnS}$ was precipitated in $\mathrm{pH}=2.4-2.5$, followed by the precipitation of nickel sulfide, $\mathrm{NiS}$ in the residual solution at $\mathrm{pH}=5.5-6.0$. It was also found that $\mathrm{Na}_{2} \mathrm{~S}$ is most effective for selective precipitation of metal sulfides, among the three sulfurating agents of $\mathrm{Na}_{2} \mathrm{~S}, \mathrm{Na}_{2} \mathrm{~S}_{2}$ and $\mathrm{Na}_{2} \mathrm{~S}_{4}$. The selectivity of CuS in the filtrated cake obtained by the sulfuration treatment in $\mathrm{pH}=1.4-1.5$ was about $94 \%$ and was sufficiently high, in terms of allowable metal content level for recycling. The sequent selectivity of $\mathrm{ZnS}$ and $\mathrm{NiS}$ in the cake after the sulfuration treatment in $\mathrm{pH}=2.4-2.5$ were $75-77 \%$ and about $20 \%$, respectively. The selectivity of NiS and $\mathrm{ZnS}$ in the cake after the sulfuration treatment in $\mathrm{pH}=5.5-6.0$ was $64-66 \%$ and $33-35 \%$, respectively.
\end{abstract}

KEYWORDS: Electroplating wastewater, Metal sulfide, Mixed metal solution, Selective recovery, Sulfuration.

\section{INTRODUCTION}

More than 100,000 tons of sludge per year which includes nickel, copper and zinc hydroxides, so far have been discharged and landfilled in Japan [1]. Recently, from the viewpoint of environmental protection and resource saving, effective recycling and reusing of the mixed sludge or the mixed-metal wastewater are strongly expected. The development of technology to separate each metal is necessary to fulfill such an increasing requirement. However, currently, there is no practical 
example of technology to recover each metal from sludge. Although there are some methods to separate a certain metal from the wastewater, such as ion exchange resin method [2]-[4], electrowinning method [5]-[7], it is difficult to apply these methods for the separation of metals from mixed-metal wastewater.

In this paper, selective separation of the metals from mixed-metal wastewater by sulfuration is presented. The sulfuration reaction of metal $(\mathrm{Me})$ ions such as $\mathrm{Cu}, \mathrm{Zn}$ and $\mathrm{Ni}$ with $\mathrm{S}^{2-}$ is considered to occur by the addition of sulfurating agent $\mathrm{Na}_{2} \mathrm{~S}_{\mathrm{X}}$ into a solution containing $\mathrm{Cu}^{2+}, \mathrm{Zn}^{2+}$ and $\mathrm{Ni}^{2+}$, to produce and precipitate metal sulfide (MeS) and sulfur. Sulfuration treatment has some advantages such as lower solubility of metal sulfides than those of metal hydroxides. The metal sulfides thus produced can be separated, even if they are in coexistence with chelating agents contained in wastewater [8].

Selective recovery of three metals namely, $\mathrm{Cu}, \mathrm{Zn}$ and $\mathrm{Ni}$, which are often used in the electroplating process, from the mixed solution containing the metals was investigated through sulfuration by adding sulfurating agents. Three kinds of sulfurating agents, namely, sodium sulfide $\left(\mathrm{Na}_{2} \mathrm{~S}\right)$, sodium disulfide $\left(\mathrm{Na}_{2} \mathrm{~S}_{2}\right)$ and sodium tetrasulfide $\left(\mathrm{Na}_{2} \mathrm{~S}_{4}\right)$ were employed for the sulfuration treatment of $\mathrm{Cu}$, $\mathrm{Zn}$, and Ni solution. We examined the influence of the amount of sulfurating agent added and the $\mathrm{pH}$ on the formation of metal sulfides precipitated.

\section{EXPERIMENTAL}

\subsection{Samples}

Table 1 shows the composition and concentration of the actual and the simulated electroplating wastewater used in the experiment. The metal sulfates, generally used in the electroplating process, $\mathrm{Cu}\left(\mathrm{SO}_{4}\right) \cdot 5 \mathrm{H}_{2} \mathrm{O}, \mathrm{Zn}\left(\mathrm{SO}_{4}\right) \cdot 7 \mathrm{H}_{2} \mathrm{O}$ and $\mathrm{Ni}\left(\mathrm{SO}_{4}\right) \cdot 6 \mathrm{H}_{2} \mathrm{O}$ were dissolved in distilled water to prepare the simulated wastewater, and the concentrations of solutions were adjusted in the range of 100-300 $\mathrm{mg} \mathrm{dm} \mathrm{m}^{-3}$.

The electroplating wastewater, that is, $\mathrm{Cu}, \mathrm{Zn}$ and Ni plating solution, was obtained from a plating shop in operation, and was diluted to $300 \mathrm{mg} \mathrm{dm}^{-3}$ for each solution of $\mathrm{Cu}, \mathrm{Zn}$ and Ni. Table 1 also shows the other compounds present in electroplating wastewater. The concentrations of aqueous solution of the three kinds of sulfurating agents, $\mathrm{Na}_{2} \mathrm{~S}, \mathrm{Na}_{2} \mathrm{~S}_{2}$ and $\mathrm{Na}_{2} \mathrm{~S}_{4}$, were adjusted to a constant concentration of $6.8 \times 10^{-2} \mathrm{~mol} \mathrm{dm}^{-3}$.

Table 1. Employed metal solution sample

\begin{tabular}{|c|c|c|c|c|}
\hline Sample solution & Sample No & Met & ation & Ingredient \\
\hline \multirow{3}{*}{$\begin{array}{c}\text { Simulated waste } \\
\text { water (single) }\end{array}$} & $1-1$ & $\mathrm{Cu}$ & 105 & $\mathrm{CuSO}_{4}$ \\
\hline & $1-2$ & $\mathrm{Zn}$ & 101 & $\mathrm{ZnSO}_{4}$ \\
\hline & $1-3$ & $\mathrm{Ni}$ & 100 & $\mathrm{NiSO}_{4}$ \\
\hline \multirow{6}{*}{$\begin{array}{l}\text { Simulated waste } \\
\text { water (mixed) }\end{array}$} & \multirow{3}{*}{$2-1$} & $\mathrm{Cu}$ & 109 & $\mathrm{CuSO}_{4}$ \\
\hline & & $\mathrm{Zn}$ & 105 & $\mathrm{ZnSO}_{4}$ \\
\hline & & $\mathrm{Ni}$ & 90.3 & $\mathrm{NiSO}_{4}$ \\
\hline & \multirow{3}{*}{$2-2$} & $\mathrm{Cu}$ & 320 & $\mathrm{CuSO}_{4}$ \\
\hline & & $\mathrm{Zn}$ & 256 & $\mathrm{ZnSO}_{4}$ \\
\hline & & $\mathrm{Ni}$ & 316 & $\mathrm{NiSO}_{4}$ \\
\hline \multirow{6}{*}{$\begin{array}{l}\text { Electroplating } \\
\text { waste water }\end{array}$} & \multirow{6}{*}{ 3-1 } & $\mathrm{Cu}$ & 97.5 & $\mathrm{CuSO}_{4}$ \\
\hline & & $\mathrm{Zn}$ & 85.3 & $\mathrm{ZnSO}_{4}$ \\
\hline & & $\mathrm{Ni}$ & 222.3 & $\mathrm{NiSO}_{4}$ \\
\hline & & $\mathrm{Fe}$ & 1.7 & \\
\hline & & & & $\mathrm{NH}_{4}(\mathrm{OH})$, EDTA \\
\hline & & & & $\begin{array}{lc}\mathrm{pH} & 2.0 \\
\text { TOC } & 55 \mathrm{mg} \mathrm{dm}^{-3}\end{array}$ \\
\hline
\end{tabular}

\subsection{Experimental procedure}

Figure 1 shows the experimental flow chart employed in this study for sulfuration treatment of wastewater which contains $\mathrm{Cu}, \mathrm{Zn}$ and $\mathrm{Ni}$. Aqueous solutions of sulfurating agents were added into $250 \mathrm{ml}$ of each sample solution. For a rough adjustment of the $\mathrm{pH}$ value of the initial metal solution, 
either $10 \mathrm{wt} \% \mathrm{H}_{2} \mathrm{SO}_{4}$ or $10 \mathrm{wt} \% \mathrm{NaOH}$ solution was used to keep the $\mathrm{pH}$ value in the predetermined range for precipitation of a specific metal sulfide. For a precise control of the $\mathrm{pH}$ value after sulfurating agents were added, $0.5 \mathrm{~mol} \mathrm{dm}^{-3} \mathrm{H}_{2} \mathrm{SO}_{4}$ was used. After the addition of sulfurating agent to the sample solution up to a prescribed amount, the solution was stirred for a time range of 30 to $60 \mathrm{~min}$, and the metal sulfide formed was filtered by using a paper filter with a mean pore size of $1 \mu \mathrm{m}$. The metal concentration of the filtrate was measured by using an ICP(P-4010, HITACHI). The sludge was dried at $378 \mathrm{~K}$ for $2 \mathrm{hrs}$, then the chemical compositions were analyzed with an XRD (Rint-2500TTR Rigaku).

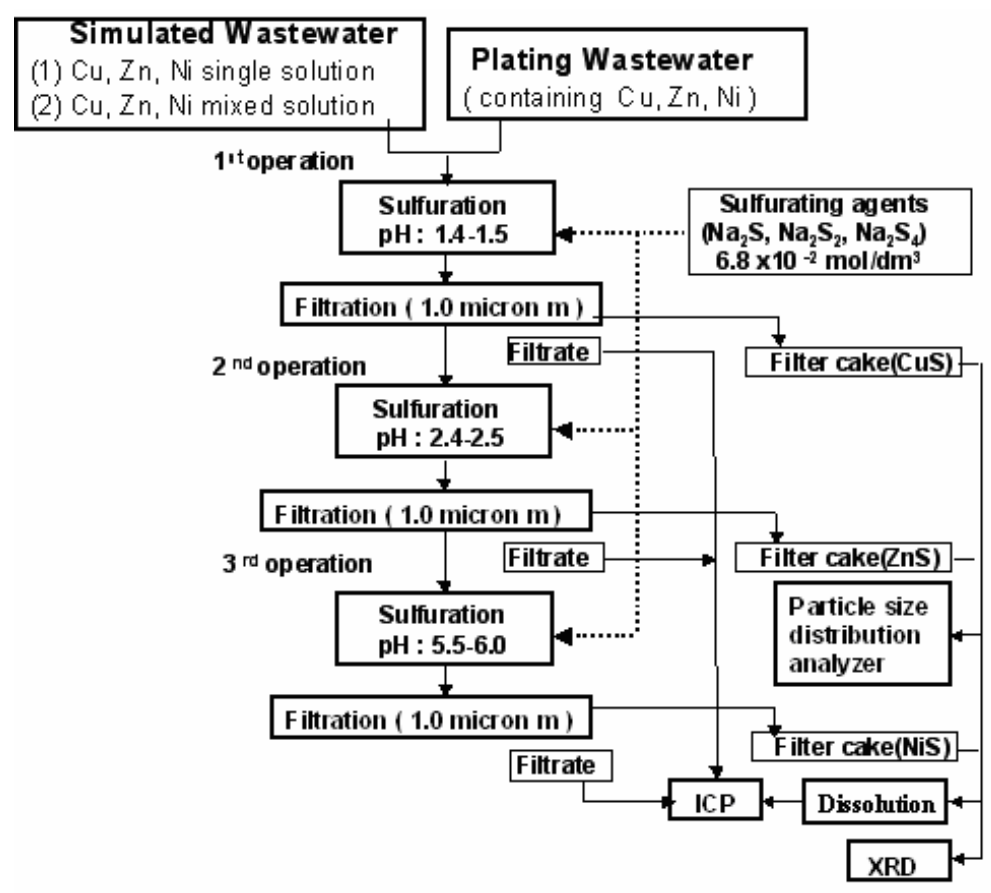

Figure 1. Experimental scheme

\section{RESULTS AND DISCUSSION}

\subsection{Mechanism of selective sulfuration of $\mathrm{Cu}, \mathrm{Zn}$ and Ni mixed metal solution}

The sulfuration reaction of metal $(\mathrm{Me})$ ions such as $\mathrm{Cu}, \mathrm{Zn}$ and Ni with $\mathrm{S}^{2-}$ is considered to occur by the addition of sulfurating agent $\mathrm{Na}_{2} \mathrm{~S}_{\mathrm{X}}$ into a solution containing $\mathrm{Cu}^{2+}, \mathrm{Zn}^{2+}$ and $\mathrm{Ni}^{2+}$, to produce metal sulfides (MeS) and sulfur (S). In general, it is known that the reaction of $\mathrm{Me}$ ions with $\mathrm{Na}_{2} \mathrm{~S}_{\mathrm{X}}$ proceeds as follows.

$\mathrm{Me}^{2+}+\mathrm{Na}_{2} \mathrm{~S}_{\mathrm{x}} \rightarrow \mathrm{MeS} \downarrow+\mathrm{Na}^{+}+(\mathrm{X}-1) \mathrm{S} \downarrow$

In the case of sulfuration of $\mathrm{Cu}$, the following two reactions may hold;

$\mathrm{Cu}^{2+}+\mathrm{Na}_{2} \mathrm{~S} \rightarrow \mathrm{CuS}+2 \mathrm{Na}^{+}$

$2 \mathrm{Cu}^{2+}+\mathrm{Na}_{2} \mathrm{~S}_{\mathrm{x}} \rightarrow \mathrm{Cu}_{2} \mathrm{~S} \downarrow+2 \mathrm{Na}^{+}+(\mathrm{X}-1) \mathrm{S} \downarrow$

In accordance with the solubility products[9], there exists the minimum $\mathrm{pH}$ values of $\mathrm{pH}=-4.75$, $\mathrm{pH}=2.5$ and $\mathrm{pH}=3.75$ for the precipitation of CuS, $\mathrm{ZnS}$ and NiS, respectively. Taking into account the effect of $\mathrm{pH}$ on the formation of metal sulfide, thermodynamic calculation of sulfuration of $\mathrm{Cu}, \mathrm{Zn}$ and $\mathrm{Ni}$ was conducted at $\mathrm{pH} 1.4-1.5, \mathrm{pH} 2.4-2.5$ and $\mathrm{pH}$ 5.5-6.0, respectively, by the use a chemical equilibrium calculation software(HSC Chemistry, Outokumpu Research Oy Information Service).

Figure 2 shows the calculation results obtained in specific conditions. From Fig. 2, it is found that CuS started to precipitate when $\mathrm{Na}_{2} \mathrm{~S}$ of $1.0 \times 10^{-6} \mathrm{kmol}$ was added to the mixed solution of $\mathrm{Cu}^{2+}$, $\mathrm{Zn}^{2+}$ and $\mathrm{Ni}^{2+}$ at an initial $\mathrm{pH}$ of 1.5. However, $\mathrm{Zn}^{2+}$ and $\mathrm{Ni}^{2+}$ was kept unreacted, except that $\mathrm{NiS}_{2}$ was formed when $\mathrm{Na}_{2} \mathrm{~S}$ of $1.5 \times 10^{-6} \mathrm{kmol}$ was added to the mixed solution. From this calculation result, it is predicted that CuS can be selectively recovered from the mixed solution of $\mathrm{Cu}^{2+}, \mathrm{Zn}^{2+}$ and $\mathrm{Ni}^{2+}$. After CuS was separated by the precipitation from the mixed solution, it was found that both $\mathrm{ZnS}$ and NiS were formed to coprecipitate at $\mathrm{pH}=2.5$. It was nevertheless expected that 
$\mathrm{Zn}$-rich precipitate was recovered, since the amount of $\mathrm{ZnS}$ precipitated was about 2 times larger than that of NiS coexisted with ZnS.
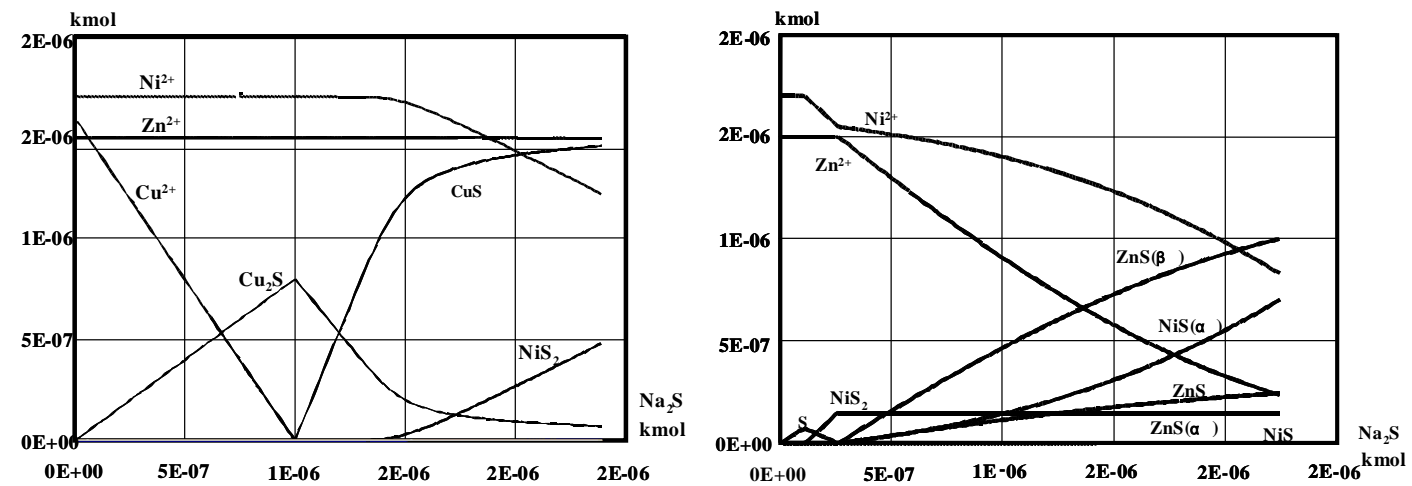

$\mathrm{Cu}, \mathrm{Zn}$ and Ni mixed solution $\mathrm{Cu}^{2+}: 1.6 \times 10^{-6} \mathrm{kmol}, \mathrm{Zn}^{2+}: 1.5 \times 10^{-6} \mathrm{kmol}$, $\mathrm{Ni}^{2+}: 1.7 \times 10^{-6} \mathrm{kmol} \mathrm{Na}_{2} \mathrm{~S}: 2.4 \times 10^{-6} \mathrm{kmol}$ $\mathrm{SO}_{4}{ }^{2-}: 5.0 \times 10^{-5} \mathrm{kmol}$ (pH: 1.5 )

$\mathrm{Zn}$ and Ni mixed solution

$\mathrm{Zn}^{2+}: 1.5 \times 10^{-6} \mathrm{kmol}, \mathrm{Ni}^{2+}: 1.7 \times 10^{-6} \mathrm{kmol}$,

$\mathrm{Na}_{2} \mathrm{~S}: 2.25 \times 10^{-6} \mathrm{kmol}$

$\mathrm{SO}_{4}^{2-}: 5.0 \times 10^{-6} \mathrm{kmol}$ (pH: 2.5$)$

Figure 2. Equilibrium on the formation of CuS, ZnS and NiS

\subsection{Optimum $\mathrm{pH}$ range for sulfuration of $\mathrm{Cu}, \mathrm{Zn}$ and $\mathrm{Ni}$}

For determining the optimum $\mathrm{pH}$ range of sulfuration of $\mathrm{Cu}, \mathrm{Zn}$ and $\mathrm{Ni}$, we referred to Charlot[9], in terms of the relation of solubility products with $\mathrm{pH}$ value. According to Charlot [9], the $\mathrm{pHs}$ for the precipitation of copper sulfide, zinc sulfide and nickel sulfide were $\mathrm{pH}=-4.75, \mathrm{pH}=2.5$ and $\mathrm{pH}=3.75$, respectively. In our preliminary test, it was found that the separation of $\mathrm{ZnS}$ and NiS was insufficient in this set of $\mathrm{pH}$ values. Hence, we adjusted the $\mathrm{pH}$ value for the sulfuration of copper at $\mathrm{pH}=1.4-1.5$, then after precipitation of CuS, the $\mathrm{pH}$ value was increased to $\mathrm{pH}=2.4-2.5$ for the sulfuration of zinc. Finally, after precipitation of $\mathrm{ZnS}$, the $\mathrm{pH}$ value was further increased to $\mathrm{pH}=$ 5.5-5.6 for the sulfuration of nickel to NiS. This set of $\mathrm{pH}$ values was most effective for selective sulfuration of copper, zinc and nickel, under the experimental condition employed.

\subsection{Selective sulfuration of simulated wastewater with $\mathrm{Na}_{2} \mathrm{~S}, \mathrm{Na}_{2} \mathrm{~S}_{2}$ and $\mathrm{Na}_{2} \mathrm{~S}_{4}$}

Based on thermodynamic calculations of sulfuration of $\mathrm{Cu}, \mathrm{Zn}$ and $\mathrm{Ni}$, we tried selective sulfuration of these metals by fixing $\mathrm{pH}$ at a certain constant value. Figure 3 shows the result of sulfuration treatment of simulated wastewater (sample No. 2-1) under a constant pH of 1.4-1.5, 2.4-2.5 and 5.5-6.0, for $\mathrm{Cu}, \mathrm{Zn}$ and $\mathrm{Ni}$, respectively by using $\mathrm{Na}_{2} \mathrm{~S}, \mathrm{Na}_{2} \mathrm{~S}_{2}$ and $\mathrm{Na}_{2} \mathrm{~S}_{4}$ as sulfurating agents. In the $\mathrm{pH}$ range of 1.4-1.5, the ratios of the concentration to the initial concentration, $\mathrm{C} / \mathrm{C}_{0}$ of $\mathrm{Zn}$ were $0.82,0.70$ and 0.60 with the addition of $\mathrm{Na}_{2} \mathrm{~S}, \mathrm{Na}_{2} \mathrm{~S}_{2}$ and $\mathrm{Na}_{2} \mathrm{~S}_{4}$, respectively, when the concentration of $\mathrm{Cu}$ in the filtrate became zero.

On the other hand, $\mathrm{C} / \mathrm{C}_{0}$ of $\mathrm{Ni}$ was $0.83,0.80$ and 0.75 with the addition of $\mathrm{Na}_{2} \mathrm{~S}, \mathrm{Na}_{2} \mathrm{~S}_{2}$ and $\mathrm{Na}_{2} \mathrm{~S}_{4}$, respectively. In the pH range of 2.4-2.5, when zinc in filtrate was no more detected, $\mathrm{C} / \mathrm{C}_{0}$ of $\mathrm{Ni}$ was about 0.65 for $\mathrm{Na}_{2} \mathrm{~S}$ and $\mathrm{Na}_{2} \mathrm{~S}_{2}$, and 0.55 for $\mathrm{Na}_{2} \mathrm{~S}_{4}$. It was found that $\mathrm{Na}_{2} \mathrm{~S}$ is the most effective sulfurating agent for selective recovery of the three metals present in the solution. A similar behavior of sulfuration of a simulated wastewater containing $300 \mathrm{~g} \mathrm{dm}^{-3}$ of each metal (sample No. 2-2) was obtained. 


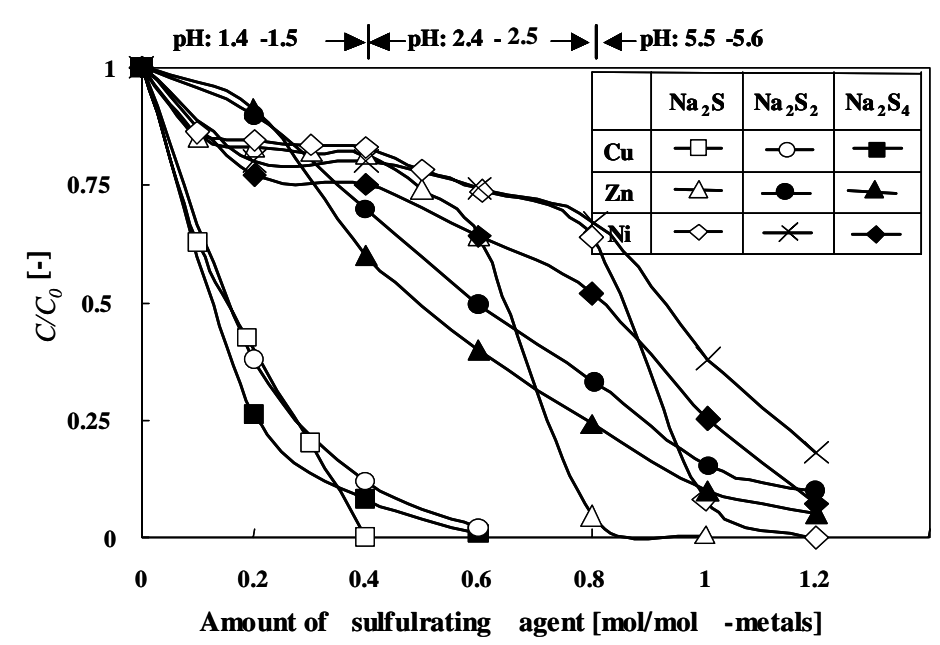

Figure 3. Concentration change of metal in filtrate of simulated mixed wastewater with addition of sulfurating agents under a constant $\mathrm{pH}$ contition

\subsection{Selective sulfuration of electroplating wastewater with $\mathrm{Na}_{2} \mathrm{~S}$ and metal yield}

The electroplating wastewater (sample No. 3-1) of the $\mathrm{pH}$ value of 2.0, which contained ammonia, EDTA and other organic components, was treated with $\mathrm{Na}_{2} \mathrm{~S}$ as the sulfurating agent under the same $\mathrm{pH}$ condition applied to the sulfuration treatment of the simulated solution; $\mathrm{pH}$ 1.4-1.5 for copper sulfide precipitation, $\mathrm{pH}$ 2.4-2.5 for zinc sulfide precipitation and $\mathrm{pH}$ 5.5-6.0 for nickel sulfide precipitation. The result is shown in Figure 4. For the sulfuration treatment of electroplating wastewater, the behaviors of concentration change $\mathrm{C} / \mathrm{C}_{0} \mathrm{~s}$ of $\mathrm{Cu}, \mathrm{Zn}$ and $\mathrm{Ni}$ in the filtrate were similar to those obtained in the sulfurating treatment of simulated solution (sample No. 2-1). There was no effect of the presence of organic components on the sulfuration of $\mathrm{Cu}, \mathrm{Zn}$ and $\mathrm{Ni}$ in the electroplating wastewater. After sulfuration treatment of samples No.2-2 and No.3-1, we measured not only the concentration of metals, $\mathrm{Cu}, \mathrm{Zn}$ and Ni, in the filtrate, but also the amount of metals contained in the filter cake. The selectivity of metals, $\mathrm{Cu}, \mathrm{Zn}$ and $\mathrm{Ni}$ contained in the filtrated cake was evaluated, which is defined as the ratio of the amount of $\mathrm{Cu}, \mathrm{Zn}$ or $\mathrm{Ni}$ to the total amount of metals of $\mathrm{Cu}, \mathrm{Zn}$ and $\mathrm{Ni}$ in the filtrated cake.

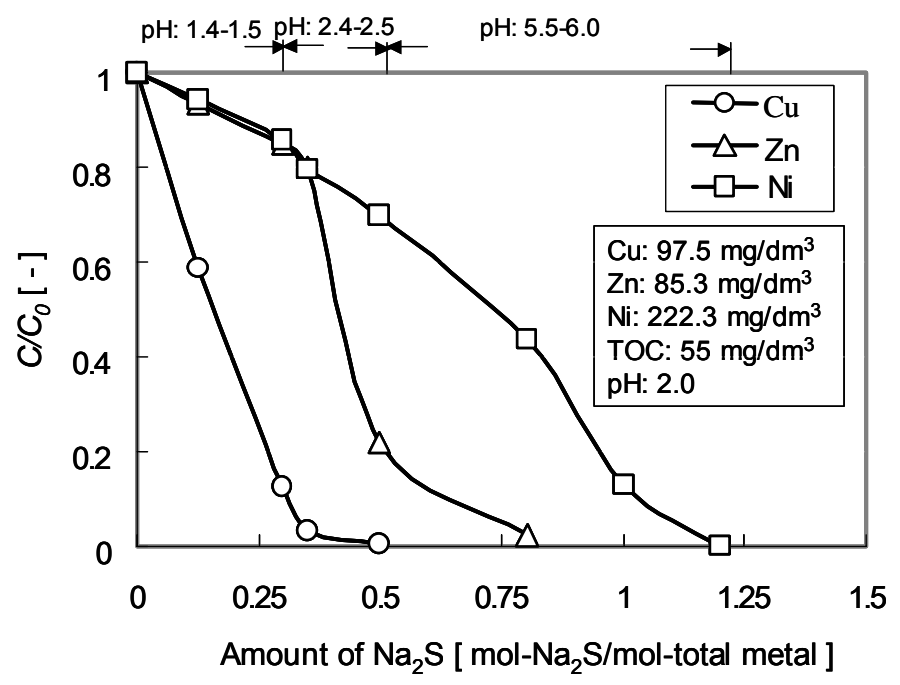

Figure 4. Concentration change of $\mathrm{Cu}, \mathrm{Zn}$ and $\mathrm{Ni}$ in fitrate of electroplating wastewater with the addition of $\mathrm{Na}_{2} \mathrm{~S}$ under a constant $\mathrm{pH}$ condition

As shown in Figure 5, the selectivity of $\mathrm{Cu}$ in the filter cake obtained by the sulfuration treatment in the $\mathrm{pH}$ range of 1.4-1.5 was about $94 \%$, and was sufficiently high to yield $\mathrm{Cu}$ acceptable for recycling. Moreover, the selectivity of $\mathrm{Zn}$ and $\mathrm{Ni}$ in the cake obtained by the sulfuration treatment 
in the $\mathrm{pH}$ range of $2.4-2.5$ was $75-77 \%$ and about $20 \%$, respectively.

The selectivity of $\mathrm{Zn}$ and $\mathrm{Ni}$ in the cake obtained by the sulfuration treatment in the $\mathrm{pH}$ range of 2.4-2.5 was $64-66 \%$ and 33-35\%, respectively. For the improvement of selectivity of $\mathrm{Zn}$ and Ni, further investigation is necessary by considering more precise control of $\mathrm{pH}$ as well as controlling the concentration of sulfurating agent, etc.

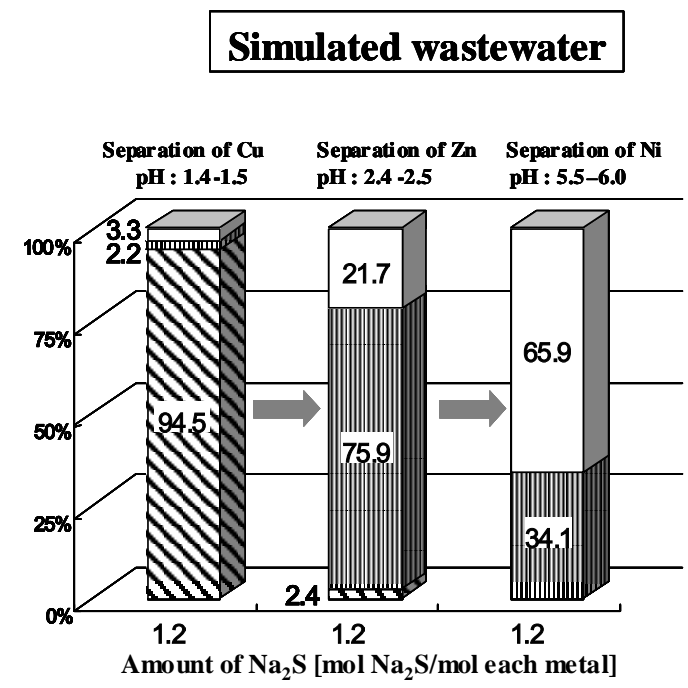

Cu IIll Zn $\square \mathrm{Ni}$

Simulated wastewater

Figure 5. Yield of metal recovery from filtrate cake

\section{Electro-plating wastewater}

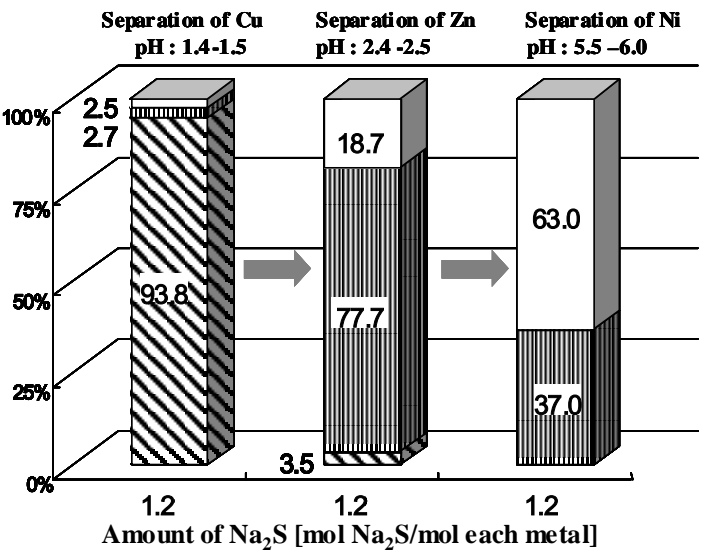

\section{CONCLUSIONS}

An attempt was made for selective recovery of copper, zinc and nickel from plating wastewater by the sulfuration treatment. In this paper, the effects of $\mathrm{pH}$ condition and sulfurating agents $\left(\mathrm{Na}_{2} \mathrm{~S}\right.$, $\mathrm{Na}_{2} \mathrm{~S}_{2}$ and $\mathrm{Na}_{2} \mathrm{~S}_{4}$ ) on selective sulfuration of copper, zinc and nickel were studied

A high selectivity of $94 \%$ of copper from a plating wastewater was obtained for the sulfuration of sample solution in the $\mathrm{pH}$ range of $\mathrm{pH}=1.4-1.5$. On the other hand, in the $\mathrm{pH}$ ranges of 2.4-2.5 and $5.5-6.0$, the selectivity of zinc and nickel was $75 \%$ and $65 \%$, respectively.

It was found that $\mathrm{Na}_{2} \mathrm{~S}$ was more effective compared with $\mathrm{Na}_{2} \mathrm{~S}_{2}$ and $\mathrm{Na}_{2} \mathrm{~S}_{4}$, in terms of higher selectivity of the three metals involved in the model solutions and the real plating solution.

\section{REFERENCES}

1. Federation of Electroplating Industry Association of Japan ed. (1993), Report of Comprehensive Recycle of Valuable Metals, Tokyo, Japan.

2. Fukuta T, (1994) Recycling of Wastewater and Metal by lon Exchange resin method, J. of Surface Finishing Society of Japan, 45, 860-864.

3. Cushnie G.C. Jr., (1994) Pollution Prevention and Control Technology for Plating Operations, 97-108.

4. Cerjan-Stefanovic S., Grubisa D. and Smid V., (1996) Separation of Copper, Nickel, Tin and Lead by Ion Exchange from Plating Rinsewater, Plating and Surface Finishing, 4, 74-79.

5. Tyson, A.G. (1984) An Electrochemical Cell for Cadmium Recovery and Recycling, Plating and Surface Finishing, 12, 44-47.

6. Dan-Bailey, (1984) High-Mass-Transfer Electrolytic Recovery, Plating and Surface Finishing, 4, 26-31.

7. Shaulys J., (1991) Cadmium Compliance Achieved With Electrowinning, Plating and Surface Finishing, 9, 42-44.

7. The Chemical Society of Japan (ed.) (1993), The Chemical Handbook Fundamental Volumes , 4th, Ed., Vol. II, Maruzen, Tokyo, Japan, 167-171.

8. Charlot, G.J. (1973), Qualitative Chemical Analysis, Kyoritu Syuppan, Tokyo, Japan, 118-121. 